\title{
Identification of Xylanase Signal Peptide in Culture Supernatant of Clostridium saccharoperbutylacetonicum Strain N1-4 Cultured on Delignified Rice Straw
}

\author{
Eri Kubota, Keiji Kiyoshi, Kosuke Nobuki, Toshimori Kadokura, Atsumi Nakazato and Shunichi Nakayama*
}

Department of Fermentation Science and Technology, Faculty of Applied Bio-science, Tokyo University of Agriculture, Setagaya-ku, Tokyo, Japan

\begin{abstract}
The butanol-producing Clostridium saccharoperbutylacetonicum strain N1-4 abundantly secreted xylanase into the culture supernatant when cultured on delignified rice straw. The xylanase signal peptide was identified based on its $\mathrm{N}$-terminal amino acid sequence and was presumed to be secreted by the Sec-system. The presence of xylanase in the medium indicated that the strain was capable of utilizing xylan as a substrate. Also, butanol production obtained using a medium supplemented with xylan was comparable to that obtained using the same strain cultured on a medium supplemented with glucose. The signal peptide facilitated the secretion of exogenous cellulases expressed by butanol-producing strains and promoted butanol production from delignified rice straw.
\end{abstract}

Keywords: Butanol production; Signal peptide; Clostridium species; Lignocellulosic biofuel; Xylanase

\section{Introduction}

The biobutanol produced by Clostridium spp. can be used as biofuel and/or as chemical feedstock [1]. Lignocellulose, such as that in rice straw, is composed of cellulose, hemicellulose and lignin and is considered to be well suited for use as a cost-effective and abundant substrate for biobutanol production [2,3]. We previously demonstrated how a co-culture of the cellulolytic Clostridium thermocellum and the butanol-producing Clostridium saccharoperbutylacetonicum strain N1-4 could be used to produce butanol from delignified rice straw, and how enhancing exoglucanase activity could be used to increase butanol production [4]. It is considered that promoting exoglucanase activity by the butanol-producing strain N1-4, which exhibits very little exoglucanase activity but possesses a host-vector system [5], could be used to cost effectively produce butanol from delignified rice straw.

To promote exoglucanase activity, the expressed enzyme should be secreted into the culture medium. Since the signal peptide sequence is required for protein secretion, the roles of exogenous and endogenous signal peptides in cellulase secretion by butanol-producing Clostridium strains have been investigated previously [6]. Although the cel48F and cel48A cellulase genes in Clostridium cellulolyticum and Clostridium acetobutylicum were challenged to be expressed with their respective native signal peptides, no transformants were obtained. However, when the signal peptide of the cel $48 \mathrm{~F}$ gene was eliminated, transformants were obtained and Cel48F was expressed in the cytosol. Based on these findings, Mingardon et al. [6] considered that growth inhibition may be related to cellulase gene expression with the signal peptide, and that the toxic effect of cellulase with the signal peptide still remained to be elucidated.

The relatively limited knowledge of protein secretion mechanisms in butanol-producing Clostridia limited efforts to increase cellulase secretion. Although the signal peptides has been predicted for $C$. acetobutylicum by genome analysis [7], the experimental identification of the signal peptide and secreted into the culture supernatant has rarely been reported. One such example is the identification of the signal sequence of the cel48F gene in C. acetobutylicum after Cel $48 \mathrm{~F}$ secretion was confirmed by concentrating the culture supernatant using cellulose affinity [8].
In another study, the gene expression patterns of the butanolproducing C. acetobutylicum ATCC 824 were altered depending on whether the substrate was glucose or cellobiose $[9,10]$, suggesting that the proteins secreted into the supernatants of cultures grown on delignified rice straw, which consists of cellulose and hemicellulose as carbon sources, differed from those produced when the substrate was glucose. It is therefore considered important for secretion of exoglucanase to identify and use those signal peptides that are abundantly secreted by butanol-producing Clostridia strains cultured on delignified rice straw, and not those that are secreted when glucose is used as the primary carbon source.

Among the protein secretion systems, the Sec system is widely distributed among Gram-positive bacteria [11]. The Sec system is composed of transmembrane component $\mathrm{SecY}, \mathrm{SecE}$, and $\mathrm{SecG}$, cytosolic ATPase SecA, auxiliary protein SecD, SecF, and YajC, and signal peptidase SPase I and SPase II and all proteins secreted by Sec system possess an $\mathrm{N}$-terminal signal peptide in C. acetobutylicum [7]. We therefore identified the N-terminal amino acid sequence of an abundantly secreted protein obtained from butanol-producing C. saccharoperbutylacetonicum strain N1-4, which is highly suitable for co-culture with C. thermocellum [12], cultured on substrates of delignified rice straw or xylan.

\section{Materials and Method}

\section{Culture conditions}

The butanol-producing C. saccharoperbutylacetonicum strain N1-4

*Corresponding authors: Shunichi Nakayama, Department of Fermentation Science and Technology, Faculty of Applied Bio-science, Tokyo University of Agriculture, Setagayaku, Tokyo, Japan, Tel: 81-3-5477-2382; E-mail: s3nakaya@nodai.ac.jp

Received October 08, 2015; Accepted October 30, 2015; Published November 06, 2015

Citation: Kubota E, Kiyoshi K, Nobuki K, Kadokura T, Nakazato A, et al. (2015) Identification of Xylanase Signal Peptide in Culture Supernatant of Clostridium saccharoperbutylacetonicum Strain N1-4 Cultured on Delignified Rice Straw. J Microb Biochem Technol 7: 394-397. doi:10.4172/1948-5948.1000244

Copyright: $\odot 2015$ Kubota E, et al. This is an open-access article distributed under the terms of the Creative Commons Attribution License, which permits unrestricted use, distribution, and reproduction in any medium, provided the original author and source are credited. 
Citation: Kubota E, Kiyoshi K, Nobuki K, Kadokura T, Nakazato A, et al. (2015) Identification of Xylanase Signal Peptide in Culture Supernatant of Clostridium saccharoperbutylacetonicum Strain N1-4 Cultured on Delignified Rice Straw. J Microb Biochem Technol 7: $394-397$. doi:10.4172/1948-5948.1000244

(ATCC 13564) was cultured anaerobically at $30^{\circ} \mathrm{C}$ in clostridial growth medium (CGM) [4\% glucose and $0.75 \mathrm{~g} \mathrm{KH}_{2} \mathrm{PO}_{4}, 0.982 \mathrm{~g} \mathrm{~K}_{2} \mathrm{HPO}_{4}, 1 \mathrm{~g}$ $\mathrm{NaCl}, 0.01 \mathrm{~g} \mathrm{MnSO}_{4}, 0.004 \mathrm{~g} p$-aminobenzoic acid, $0.348 \mathrm{~g} \mathrm{MgSO}_{4}, 0.01$ $\mathrm{g} \mathrm{FeSO}, 2 \mathrm{~g}$ asparagine, $5 \mathrm{~g}$ yeast extract, $2 \mathrm{~g}\left(\mathrm{NH}_{4}\right)_{2} \mathrm{SO}_{4}$ and $40 \mathrm{~g}$ glucose per liter ( $\mathrm{pH}$ 6.5)]. The strains were cultured in test tubes stoppered with a butyl rubber stoppers after substitution of the headspace with nitrogen gas. After $24 \mathrm{~h}$ cultivation, the cells were collected by centrifugation, washed, resuspended in CGM medium without any added carbon source, and adjusted to $\mathrm{OD}_{600 \mathrm{~nm}}=5$. Ten milliliters of the cell suspension was then used to inoculate separate $90 \mathrm{ml}$ samples of CGM medium containing glucose, cellobiose, xylan from beechwood (Sigma-Aldrich Corp., St. Louis, MO), or delignified rice straw (final $\left.\mathrm{OD}_{600 \mathrm{~nm}}=0.5\right)$ and incubated at $30^{\circ} \mathrm{C}$ for $24 \mathrm{~h}$. The delignified rice straw substrate was prepared as described previously [4].

\section{Analytical procedure}

Fermentation products in the culture supernatant were quantified by HPLC (Aminex HPX-87H column, Bio-Rad Laboratories K.K., Japan) using a differential refractive index detector (Shimadzu Corporation, Japan) and an aqueous solution of $0.05 \mathrm{mM} \mathrm{H}_{2} \mathrm{SO}_{4}$ as the solvent at a flow rate of $0.7 \mathrm{ml} / \mathrm{min}$. A spectrophotometer (U-2001; Hitachi Ltd., Japan) was used to measure OD.

\section{Collection of crude extracellular protein}

The $100 \mathrm{ml}$ culture supernatants from the glucose, cellobiose, xylan or delignified rice straw cultures were obtained by centrifugation of culture media $\left(16,000 \times \mathrm{g}, 10 \mathrm{~min}, 4^{\circ} \mathrm{C}\right)$. The crude extracellular proteins in the culture supernatants were precipitated with $80 \%$ ammonium sulfate and collected by centrifugation $\left(400 \times \mathrm{g}, 15 \mathrm{~min}, 4^{\circ} \mathrm{C}\right)$. The pellets were resuspended and dialyzed with $50 \mathrm{mM}$ phosphate buffer ( $\mathrm{pH}$ 6.86). The dialyzed protein solutions were then concentrated by ultrafiltration (Amicon Ultra Ultracel-30K; Millipore Ireland, Ltd, UK). The protein concentration of each sample was measured by the Bradford method using Coomassie Protein Assay Reagent (Thermo Fisher Scientific, Inc., MA) and a standard curve plotted using bovine serum albumin.

\section{Amino acid sequencing}

The crude extracellular proteins were subjected to SDS-PAGE on a $10 \%$ poly-acrylamide gel and then transferred to an Immun-Blot PVDF membrane (Bio-Rad Laboratories, Inc., CA) by electro blotting and stained with Coomassie blue. The protein bands, indicated as bands No. 1 to 4 shown in Figure 1, were then excised from the membrane and the $\mathrm{N}$-terminal amino acid sequences of each protein were determined using a gas-phase amino acid sequencer (Procise 494 HT Protein Sequencing System, APRO Life Science Institute, Inc, Japan). Homology sequence analysis of the N-terminal amino acids was performed against the genome sequence of Clostridium saccharoperbutylacetonicum ATCC 27021 derived from strain N1-4 (ATCC 13564) [12].

\section{Enzyme assay}

The $100 \mathrm{ml}$ culture supernatants from the glucose, xylan or delignified rice straw cultures were obtained by centrifugation of culture media $\left(16,000 \times \mathrm{g}, 10 \mathrm{~min}, 4^{\circ} \mathrm{C}\right)$. The crude extracellular enzyme was collected by ultrafiltration of the culture medium supernatant (Amicon Ultra Ultracel-30K; Millipore Ireland, Ltd, UK). The filtrate was then substituted with $50 \mathrm{mM}$ Britton and Robinson's universal buffer (50 $\mathrm{mM}$ phosphoric acid, $50 \mathrm{mM}$ boric acid, and $50 \mathrm{mM}$ acetic acid: $\mathrm{pH}$ was adjusted to 5.0 with $\mathrm{NaOH}$ ) [13]. The xylanase activity in the

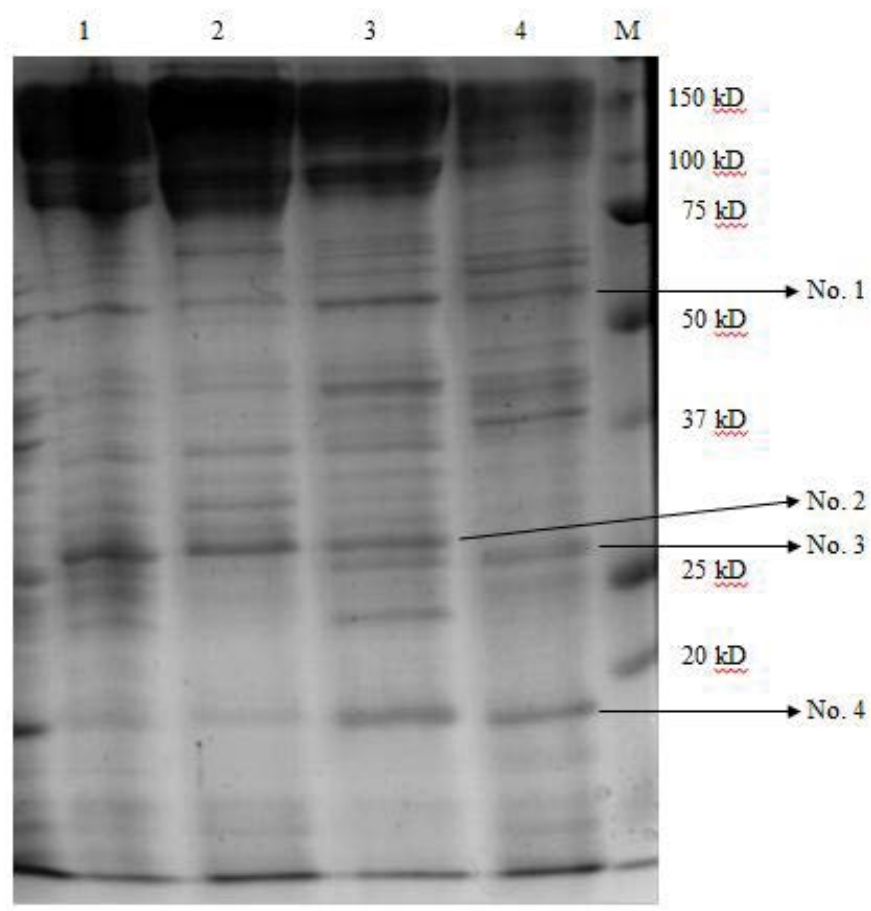

Figure 1: SDS-PAGE analysis of $2 \mathrm{mg}$ of crude extracellular proteins secreted by strain N1-4 cultured on the following substrates. Lane 1: glucose; 2: cellobiose; 3: xylan; 4: delignified rice straw; M: Precision Plus Protein ${ }^{\mathrm{TM}}$ Prestained Standards (10 - $250 \mathrm{kD})$.

crude extracellular proteins was measured based on beechwood xylan (Sigma-Aldrich Corp.) degradation activity at $30^{\circ} \mathrm{C}[14,15]$. One unit of specific activity of xylanase activity was defined as one micromole of released reducing sugars (as xylose equivalents) per milligram protein per minute. A spectrophotometer (U-2001; Hitachi Ltd., Japan) was used for the enzyme assays.

\section{Results and Discussion}

\section{Identification of proteins secreted into the supernatants of cultures grown on different substrates}

The C. saccharoperbutylacetonicum strain N1-4 was cultured on CGM medium containing glucose, cellobiose, xylan or delignified rice straw; cellobiose and xylan were selected as they are components of rice straw [16]. After $24 \mathrm{~h}$ of cultivation, strain N1-4 produced $1.9 \pm 0.1 \mathrm{~g} / \mathrm{L}$, $1.7 \pm 0.1 \mathrm{~g} / \mathrm{L}, 1.6 \pm 0.2 \mathrm{~g} / \mathrm{L}$, and $0.1 \pm 0.0 \mathrm{~g} / \mathrm{L}$ of butanol in CGM medium containing $1 \%$ glucose, cellobiose, xylan, and delignified rice straw, respectively. The low levels of butanol production on delignified rice straw was expected as strain N1-4 exhibits very little cellulase activity $[4,12]$. As with other butanol-producing strains, strain N1-4 produced the almost same amount of butanol on media containing xylan as it did on media containing glucose $[17,18]$. Although xylose and glucose had to be added to the culture medium in the case of $C$. acetobutylicum to support the initial growth, strain N1-4 did not require the additional carbon supplementation with glucose. This result suggests that the strain N1-4 secretes sufficient quantities xylanase into the culture supernatant to achieve xylan utilization.

The SDS-PAGE gel of the proteins in the supernatants obtained from cultures using glucose, cellobiose, xylan or delignified rice straw as substrates is shown in Figure 1. As expected, the secreted 
Citation: Kubota E, Kiyoshi K, Nobuki K, Kadokura T, Nakazato A, et al. (2015) Identification of Xylanase Signal Peptide in Culture Supernatant of Clostridium saccharoperbutylacetonicum Strain N1-4 Cultured on Delignified Rice Straw. J Microb Biochem Technol 7: $394-397$. doi:10.4172/1948-5948.1000244

proteins differed according to the substrate. N-terminal amino acid sequence analysis was not able to distinguish band No. 1 in the delignified rice straw sample due to the presence of more than one protein. The N-terminal amino acid sequence of band No. 3 in the delignified rice straw sample was MKKIFV, which showed homology with 3-hydroxybutyryl-CoA dehydrogenase (GI:505203479). Since 3-hydroxybutyryl-CoA dehydrogenase, which converts acetoacetylCoA to 3-hydroxybutyryl-CoA and is an important enzyme for butanol production in the cytosol [19], showed no signal peptide, we assumed that the presence of this protein could be attributed to cell lysis. Band No. 2, which was obtained from the supernatant of the culture that used xylan as a substrate, was comprised of two proteins (-DDSVAAand -CNQATL-) that showed homology with the hypothetical proteins GI:505207329 and GI:505207583, respectively. The function of these two proteins hardly predicted from the homology analysis. The $\mathrm{N}$-terminal amino acid sequence of band No. 4 from the delignified rice straw culture was ATTDYW and showed homology with xylanase (GI:505205227). Interestingly, the band corresponding to the identified xylanase in the delignified rice straw culture was also detected in the supernatant of the xylan culture, and only slightly in the crude extracellular protein of the glucose culture. These findings suggest that the identified xylanase was induced by the presence of xylan, because delignified rice straw also contains xylan in hemicellulose. The detection of the xylanase implied that the strain can utilize xylan to produce butanol with the same efficiency as glucose. In accordance with the fact the xylanase is induced by xylan or delignified rice straw, the xylanase activity of crude extracellular enzymes from cultured by xylan and delignified rice straw was $6.0(19.3 \pm 0.4 \mathrm{mU} / \mathrm{mg})$ and 6.5 fold $(20.7 \pm 1.5 \mathrm{mU} / \mathrm{mg})$ higher than that of glucose grown culture $(3.2$ $\pm 0.1 \mathrm{mU} / \mathrm{mg}$ ), respectively (Figure 2 ).

The finding that the secretion of the xylanase protein was repressed by glucose and induced by both xylan and delignified rice straw could be useful for isolating transformants expressing the cellulase gene. Although cellulase-secreting transformants have been obtained for butanol-producing Clostridia, the isolation of the transformants expressing the cellulase genes was likely complicated by the toxicity of the signal peptide required for protein secretion [6]. Transformants

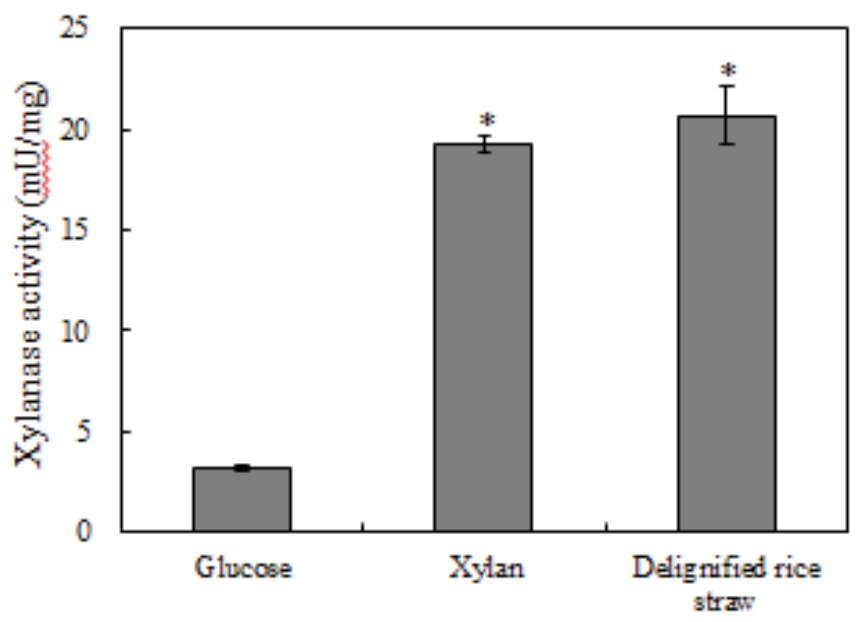

Figure 2: Comparison of xylanase activity $(\mathrm{mU} / \mathrm{mg})$ in crude extracellular enzymes cultured by glucose, xylan, and delignified rice straw. The means and standard deviation of experiments performed in triplicate are shown. Asterisk shows where obtained data were significantly different to crude extracellular enzymes from cultured by glucose $(\mathrm{P}<0.01)$. harboring a cellulase expression plasmid with the signal peptide under the control of a promotor that is repressed by glucose and that is induced by either xylan or delignified rice straw could be obtained with relative ease. Essentially, the transformants could be screened using a culture medium containing glucose, as the toxic cellulase with the signal peptide would not be expressed under these conditions. After that, even if the signal peptide is toxic, the mutant strains showed no toxicity by signal sequence and effectively secreting cellulase in the culture containing delignified rice straw would be obtained by the mutation. The expression mechanism of xylanase by the extracytoplasmic sigma factor has been reported in C. thermocellum [20]. Since $C$. saccharoperbutylacetonicum also possesses an extracytoplasmic sigma factor that shows high homology with that of $C$. thermocellum (i.e., based on genome sequence analysis), similar regulatory mechanisms may be employed by both bacteria. Further analysis is considered necessary in order to elucidate the regulatory mechanisms underlying the induction of xylanase expression.

\section{Comparison of signal peptide sequences among the secreted proteins}

A putative ribosome binding site showing high homology was not observed in the region $10 \mathrm{bp}$ upstream of the three sequenced peptides (i.e., No. 2 and No. 4); however, a putative initiation codon and ribosome binding site were identified more than $65 \mathrm{bp}$ upstream of the sequenced peptides. This finding implies that the amino acid sequences were truncated and that the signal peptide was contained in these truncated peptides. The amino acid sequences of the signal peptides of the three secreted proteins are listed in Table 1.

The Sec-dependent signal peptide sequence is composed of a positively charged $\mathrm{N}$-terminal domain (n-domain), hydrophobic core region (h-domain), and a c-domain with a consensus signal peptidase recognition site digested with SPase I or SPase II [7]. Signal sequence predictions based on genome analysis in C. acetobutylicum showed that the average length of an $n$-domain with $2-3$ positively charged amino acids, such as lysine or arginine, and an h-domain of 10 and 19 residues [7]. In accordance with this prediction, the $\mathrm{n}$-domain and h-domain of the identified xylanase and the hypothetical protein showed homology with GI: 505207329 contained 7 and 5 residues with lysine or arginine in the n-domain, and 20 and 18 residues with hydrophobic amino acids in the h-domain. Consensus sequences of the c-domain cleaved with SPase I and SPase II were predicted as (V/A/I)-(K/F/Y)-A, and (L/F/I)(T/S/V/A)-(G/A/S)-C, respectively [7]. The c-domain of the xylanase and hypothetical protein closely matched the consensus sequence of SPase I, suggesting that these proteins would be cleaved by SPase I.

The hypothetical protein showing homology with GI: 505207583 also contains typical $\mathrm{n}$-domain and h-domain regions, while the sequence of the c-domain was initiated with a cysteine residue and showed homology with the consensus sequence of the cleavage site of SPase II, indicating that this protein is cleaved by SPaseII. Since most proteins cleaved by SPase II are lipoproteins [7], the hypothetical protein is suggested to be a lipoprotein even though the actual function in strain N1-4 is unknown.

Genes homologous to Sec-dependent secretion system have been found in the C. saccharoperbutylacetonicum genome (secY: CSPA_ RS01025, secE: CSPA_RS00860 secG: CSPA_RS24810, and secA: CSPA_RS03170), and the three proteins identified in this study also appear to correspond to those of the Sec system. 
Citation: Kubota E, Kiyoshi K, Nobuki K, Kadokura T, Nakazato A, et al. (2015) Identification of Xylanase Signal Peptide in Culture Supernatant of Clostridium saccharoperbutylacetonicum Strain N1-4 Cultured on Delignified Rice Straw. J Microb Biochem Technol 7: $394-397$. doi:10.4172/1948-5948.1000244

\begin{tabular}{|c|c|c|c|c|c|c|c|}
\hline \multirow{2}{*}{ The band number } & \multirow{2}{*}{$\begin{array}{c}\text { Homologous } \\
\text { protein }\end{array}$} & \multirow{2}{*}{ Protein function } & \multicolumn{3}{|c|}{ Signal peptide } & \multirow{2}{*}{$\begin{array}{c}\text { Sequenced amino } \\
\text { acid }\end{array}$} & \multirow{2}{*}{ Type of SPase } \\
\hline & & & n-domain & h-domain & c-domain & & \\
\hline 4 & GI:505205227 & Xylanase & MKKRGLK & LFLASLMCCTLALSVVNVN & TNA & ATTDYW & SPase I \\
\hline 2 & Gl:505207329 & Hypothetical protein & MKKNK & ILGIAIAAIIGMTSMVP & AFA & DDSVAA & SPase I \\
\hline 2 & Gl:505207583 & Hypothetical protein & MKMKK & TLAIIMTAALAAGT & LAG & CNQATL & SPase II \\
\hline
\end{tabular}

The positively charged $n$-domain is indicated in bold letters. The amino acid residue not sequenced by amino acid sequencer is underlined

Table 1: Characterization of signal peptide identified in this study.

\section{Conclusion}

In this study, a signal peptide abundantly secreted by $C$. saccharoperbutylacetonicum strain N1-4 cultured media supplemented with xylan or delignified rice straw was identified. The xylanase signal peptide was presumed to be secreted by the Sec-system and was cleaved with SPase I. It is expected that the expression of exoglucanase using signal peptide and inducible promoter of xylanase identified in this study will be applied to butanol production from delignified rice straw to further improve its productivity.

\section{References}

1. Dürre $P$ (2007) Biobutanol: an attractive biofuel. Biotechnol J 2: 1525-1534.

2. Maki M, Leung KT, Qin W (2009) The prospects of cellulase-producing bacteria for the bioconversion of lignocellulosic biomass. Int J Biol Sci 5: 500-516.

3. Binod P, Sindhu R, Singhania RR, Vikram S, Devi L, et al. (2010) Bioethano production from rice straw: An overview. Bioresour Technol 101: 4767-4774.

4. Kiyoshi K, Furukawa M, Seyama T, Kadokura T, Nakazato A, et al. (2015) Butanol production from alkali-pretreated rice straw by co-culture of Clostridium thermocellum and Clostridium saccharoperbutylacetonicum. Bioresour Technol 186: 325-328.

5. Nakayama S, Irie R, Kosaka T, Matsuura K, Yoshino S, et al. (2007) New hostvector system in solvent-producing Clostridium saccharoperbutylacetonicum strain N1-4. J Gen Appl Microbiol 53: 53-56.

6. Mingardon F, Chanal A, Tardif C, Fierobe HP (2011) The issue of secretion in heterologous expression of Clostridium cellulolyticum cellulase-encoding genes in Clostridium acetobutylicum ATCC 824. Appl Environ Microbiol 77: 2831-2838.

7. Desvaux M, Khan A, Scott-Tucker A, Chaudhuri RR, Pallen MJ, et al. (2005) Genomic analysis of the protein secretion systems in Clostridium acetobutylicum ATCC 824. Biochim Biophys Acta 1745: 223-253.

8. Sabathé F, Bélaïch A, Soucaille $P$ (2002) Characterization of the cellulolytic complex (cellulosome) of Clostridium acetobutylicum. FEMS Microbiol Lett 217: 15-22.

9. Servinsky MD, Kiel JT, Dupuy NF, Sund CJ (2010) Transcriptional analysis of differential carbohydrate utilization by Clostridium acetobutylicum. Microbiology 156: $3478-3491$

10. López-Contreras AM, Gabor K, Martens AA, Renckens BA, Claassen PA, et al. (2004) Substrate-induced production and secretion of cellulases by Clostridium acetobutylicum. Appl Environ Microbiol 70: 5238-5243.

11. Tjalsma H, Bolhuis A, Jongbloed JD, Bron S, van Dijl JM (2000) Signal peptidedependent protein transport in Bacillus subtilis: a genome-based survey of the secretome. Microbiol Mol Biol Rev 64: 515-547.

12. Nakayama S, Kiyoshi K, Kadokura T, Nakazato A (2011) Butanol production from crystalline cellulose by co-cultured Clostridium thermocellum and Clostridium saccharoperbutylacetonicum N1-4. Appl Environ Microbiol 77 : 6470-6475

13. Del Cerro C, Felpeto-Santero C, Rojas A, Tortajada M, Ramón D, García JL (2013) Genome Sequence of the Butanol Hyperproducer Clostridium saccharoperbutylacetonicum N1-4. Genome Announc 1: e0007013

14. Kosugi A, Murashima K, Doi RH (2002) Characterization of two noncellulosomal subunits, ArfA and BgaA, from Clostridium cellulovorans that cooperate with the cellulosome in plant cell wall degradation. J Bacteriol 184: 6859-6865.

15. Chundawat SP, Lipton MS, Purvine SO, Uppugundla N, Gao D, et al. (2011) Proteomics-based compositional analysis of complex cellulase-hemicellulase mixtures. J Proteome Res 10: 4365-4372.

16. Saha BC (2003) Hemicellulose bioconversion. J Ind Microbiol Biotechnol 30: 279-291.

17. Qureshi N, Li XL, Hughes S, Saha BC, Cotta MA (2006) Butanol production from corn fiber xylan using Clostridium acetobutylicum. Biotechnol Prog 22: 673-680.

18. Rajagopalan G, He J, Yang KL (2014) Direct fermentation of xylan by Clostridium strain $\mathrm{BOH} 3$ for the production of butanol and hydrogen using optimized culture medium. Bioresour Technol 154: 38-43.

19. Jones DT, Woods DR (1986) Acetone-butanol fermentation revisited. Microbio Rev 50: 484-524.

20. Nataf $Y$, Bahari L, Kahel-Raifer H, Borovok I, Lamed R, Bayer EA, Sonenshein $\mathrm{AL}$, Shoham $\mathrm{Y}$ (2010) Clostridium thermocellum cellulosomal genes are regulated by extracytoplasmic polysaccharides via alternative sigma factors. Proc Natl Acad Sci USA 107: 18646-18651 